\title{
Czy hale namiotowe podlegają podatkowi od nieruchomości?
}

\section{Are tent halls subject to property tax?}

Streszczenie. Prezentowana publikacja jest odpowiedzią na aktualnie stawiane pytania i wątpliwości interpretacyjne podatników oraz organów podatkowych, a mianowicie, czy hale namiotowe podlegają podatkowi od nieruchomości. Zaprezentowano w niej ogólne zagadnienia związane z podmiotem i przedmiotem opodatkowania tym podatkiem. Następnie poprzez dokonaną kwalifikację obiektów budowlanych oraz przypisanie hal namiotowych do właściwej im kategorii obiektów, posługując się aktualnie obowiązującymi przepisami prawa, udzielono odpowiedzi na pytanie zadane w tytule przedmiotowej publikacji.

Słowa kluczowe: prawo; prawo podatkowe; podatki; podatek od nieruchomości; interpretacja prawa.

Abstract. The presented publication is a response to currently asked questions and interpretative doubts of taxpayers and tax authorities, namely whether tent halls are subject to property tax. General issues connected with an entity and a subject of taxation of this tax are presented herein. The answer to the question asked is then provided through the qualification of constructions works and the 
allocation of tent halls in the proper category of the works, with the use of the current law.

Keywords: law; tax law; taxes; property tax; interpretation of law.

\section{Uwagi ogólne}

Prawo podatkowe sięga do wielu sfer życia społecznego oraz gospodarczego. Zarówno obarcza ono swoim ciężarem prywatną i wyspecjalizowaną (zawodową) aktywność podmiotów tego prawa, jak i nie pozostaje obojętne wobec materialnych stanów prawnych związanych z posiadaniem zasobów majątkowych (rzeczy). Każdy z podatków charakteryzuje różny przedmiot opodatkowania, a przez wolę ustawodawcy i decentralizację zadań publicznych, stanowi dochód budżetu państwa albo dochód jednostki samorządu terytorialnego (gminy) ${ }^{1}$.

Podatek od nieruchomości jest podatkiem, który zasila dochody gmin i dzięki któremu gminy uzyskują największe wpływy podatkowe. Przy czym największe wpływy generują wielkie metropolie, co jest oczywiste z uwagi na ich obszar, urbanizację, infrastrukturę, a także zagęszczoną liczbę podmiotów prowadzących pozarolniczą działalność gospodarczą, co ma znaczenie dla wyższego poziomu opodatkowania przedmiotów zajętych na jej prowadzenie.

Podatek od nieruchomości jest obecny w polskim systemie podatkowym od początku 1991 r., uregulowany ustawą z dnia 19 stycznia 1991 r. o podatkach i opłatach lokalnych ${ }^{2}$.

\section{Przedmiot i podmiot opodatkowania}

W świetle art. 2 u.p.o.l. opodatkowaniu podatkiem od nieruchomości podlegają następujące nieruchomości lub obiekty budowlane:

\footnotetext{
1 Wyłącznie gmina w strukturze jednostek samorządu terytorialnego posiada własne dochody podatkowe. Nie należy tego mylić z udziałem we wpływach z podatków dochodowych, które to należą się również powiatowi i województwu.

2 Tekst jedn. Dz.U. z 2014 r., poz. 849 ze zm., dalej: u.p.o.l.
} 
- grunty,

- $\quad$ użytki rolne, grunty zadrzewione i zakrzewione na użytkach rolnych lub lasy, zajęte na prowadzenie działalności gospodarczej,

- $\quad$ budynki lub ich części,

- budowle lub ich części związane z prowadzeniem działalności gospodarczej.

Powyższy katalog jest katalogiem zamkniętym i obejmuje przedmioty materialne (obiekty), w istocie rzeczy, zgodne z cywilistyczną definicją nieruchomości, regulowaną treścią art. 46 ustawy z dnia 23 kwietnia 1964 r. - Kodeks cywilny ${ }^{3}$.

Na marginesie wypada przypomnieć za Trybunałem Konstytucyjnym, że od nazwy podatku nie można jednak oczekiwać aż takiej szczegółowości w wyznaczaniu tytułów prawnych, jakie powodowałyby powstanie obowiązku podatkowego ${ }^{4}$. Stąd też, sama nazwa podatku w zasadzie powinna być adekwatna i komunikatywna, jednakże nie może ograniczać ustawodawcy w możliwości obejmowania konkretną daniną innych przedmiotów opodatkowania, które nie w pełni odpowiadają ścisłej definicji zawartej w tytule ustawy (w badanym zakresie wyłącznie nieruchomości).

Tak też ustawodawca uczynił w u.p.o.l. poprzez objęcie jej zakresem również innych obiektów budowlanych, niebędących z definicji nieruchomościami, a mianowicie budowli. Podlegają one opodatkowaniu podatkiem od nieruchomości, jednak w ściśle określonych warunkach, o których szerzej w dalszej części analizy.

Podatnikami podatku od nieruchomości są natomiast osoby fizyczne oraz prawne, jednostki organizacyjne, w tym spółki nieposiadające osobowości prawnej, będące:

- $\quad$ właścicielami i posiadaczami samoistnymi nieruchomości lub obiektów budowlanych;

- $\quad$ użytkownikami wieczystymi gruntów;

3 Nieruchomościami są części powierzchni ziemskiej stanowiące odrębny przedmiot własności (grunty), a także budynki trwale z gruntem związane lub części takich budynków, jeżeli na mocy przepisów szczególnych stanowią odrębny od gruntu przedmiot własności.

4 Wyrok Trybunału Konstytucyjnego z dnia 13 września 2011 r., sygn. akt P 33/09, Dz.U. Nr 206, poz. 1228. 
- $\quad$ posiadaczami nieruchomości lub ich części albo obiektów budowlanych lub ich części, stanowiących własność Skarbu Państwa lub jednostki samorządu terytorialnego, jeżeli posiadanie wynika z umowy zawartej z właścicielem, Agencją Nieruchomości Rolnych lub z innego tytułu prawnego, z wyjątkiem posiadania przez osoby fizyczne lokali mieszkalnych niestanowiących odrębnych nieruchomości, a także wówczas, gdy posiadanie to jest bez tytułu prawnego.

Istotne zastrzeżenie należy poczynić w odniesieniu do stanu faktycznego czy prawnego posiadania lub wykorzystywania obiektu objętego podatkiem od nieruchomości, bowiem będzie on obciążał każdy podmiot, we władaniu i posiadaniu którego ten obiekt się znajduje. Władanie to nie jest związane wyłącznie z własnością obiektu, wystarczy obiekt ten posiadać oraz znaleźć się w okolicznościach uzasadniających powstanie obowiązku podatkowego.

\section{Budowla jako obiekt budowlany}

Przepisy u.p.o.l. nie definiują wprost pojęcia budowli dla potrzeb opodatkowania ich podatkiem od nieruchomości. Ustawodawca posłużył się w niniejszym akcie prawa podatkowego, tzw. przepisem odsyłającym (definicją legalną zawartą w innym akcie normatywnym). Zgodnie $\mathrm{z}$ art. 1a ust. 1 pkt 1 u.p.o.l. budowla to obiekt budowlany w rozumieniu przepisów prawa budowlanego niebędący budynkiem lub obiektem małej architektury, a także urządzenie budowlane w rozumieniu przepisów prawa budowlanego związane z obiektem budowlanym, które zapewnia możliwość użytkowania obiektu zgodnie z jego przeznaczeniem. Ustawa z dnia 7 lipca 1994 r. - Prawo budowlane ${ }^{5}$ definiuje w art. 3 pkt 1 obiekt budowlany, jako:

- $\quad$ budynek wraz z instalacjami i urządzeniami technicznymi,

- budowlę stanowiącą całość techniczno-użytkową wraz z instalacjami i urządzeniami,

- $\quad$ obiekt małej architektury.

$5 \quad$ Tekst jedn. Dz.U. z 2016 r., poz. 290 ze zm, dalej: u.p.b. 
Przez budowlę natomiast, zgodnie z treścią art. 3 ust. 1 pkt 3 cytowanej ustawy, należy rozumieć każdy obiekt budowlany niebędący budynkiem lub obiektem małej architektury, jak: obiekty liniowe, lotniska, mosty, wiadukty, estakady, tunele, przepusty, sieci techniczne, wolno stojące maszty antenowe, wolno stojące trwale związane $\mathrm{z}$ gruntem urządzenia reklamowe, budowle ziemne, obronne (fortyfikacje), ochronne, hydrotechniczne, zbiorniki, wolno stojące instalacje przemysłowe lub urządzenia techniczne, oczyszczalnie ścieków, składowiska odpadów, stacje uzdatniania wody, konstrukcje oporowe, nadziemne i podziemne przejścia dla pieszych, sieci uzbrojenia terenu, budowle sportowe, cmentarze, pomniki, a także części budowlane urządzeń technicznych (kotłów, pieców przemysłowych, elektrowni wiatrowych, elektrowni jądrowych i innych urządzeń) oraz fundamenty pod maszyny i urządzenia jako odrębne pod względem technicznym części przedmiotów składających się na całość użytkową.

Pierwsze wnioski, jakie płyną z lektury powołanych wyżej przepisów, wskazują, iż budowla stanowi bez wątpienia obiekt budowlany niebędący budynkiem lub obiektem małej architektury. Analizując dalej powyższą definicję, uznać należy z całą pewnością, że jest ona bardzo kazuistyczna, co więcej ustawodawca jej zakresem starał się objąć jak najwięcej rzeczy (obiektów) niestanowiących nieruchomości, a będących obiektami budowlanymi uznanymi jako budowle.

Można odnieść wrażenie, że powołana wyżej kazuistyka przepisu jest celowym zabiegiem prawodawcy, pozwalającym na jednoznaczne odtworzenie jego normatywu, poprzez konkretne nazwanie określonych rzeczy (obiektów), a przez to zaliczenie ich do zakresu nazwy „budowla” dla potrzeb opodatkowania ich podatkiem od nieruchomości. Taki sposób postrzegania omawianej konstrukcji prawnej wydaje się logiczny i nienastręczający większych problemów interpretacyjnych. To z kolei nie powinno generować jakichkolwiek trudności w rozstrzygnięciu, kiedy mamy do czynienia z budowlą podlegającą opodatkowaniu podatkiem od nieruchomości, bowiem to ustawodawca wymienił te obiekty expressis verbis w u.p.b., co więcej dokonał tego w konkretnej jednostce redakcyjnej. 
Wskazać przy tym należy, że w zakresie opodatkowania budowli pojawia się jednakże wiele wątpliwości i kłopotów interpretacyjnych, m.in. w zakresie ustalania ich wartości. Stąd też pojawiły się postulaty, iż należałoby albo zlikwidować pojęcie budowli, albo nazwać nią ściśle określone obiekty ujęte w klasyfikacji środków trwałych. Pomysłem godnym rozważenia mogłoby być ujęcie ich w specjalnym załączniku do ustawy. To samo można zrobić również z budynkami ${ }^{6}$.

\section{Hala namiotowa a opodatkowanie podatkiem od nieruchomości}

Punktem wyjścia do uzyskania odpowiedzi na pytanie, czy hala namiotowa jest budowlą podlegającą opodatkowaniu podatkiem od nieruchomości, jest posłużenie się przywołanymi wyżej przepisami, a następnie powiązanie ich ze znaczeniem pojęcia, tzw. tymczasowego obiektu budowlanego, którego definicję zawarto w art. 3 pkt 5 u.p.b.

Przez tymczasowy obiekt budowlany należy więc rozumieć:

- $\quad$ obiekt budowlany przeznaczony do czasowego użytkowania w okresie krótszym od jego trwałości technicznej, przewidziany do przeniesienia w inne miejsce lub rozbiórki; a także

- $\quad$ obiekt budowlany niepołączony trwale z gruntem, jak: strzelnice, kioski uliczne, pawilony sprzedaży ulicznej i wystawowe, przekrycia namiotowe i powłoki pneumatyczne, urządzenia rozrywkowe, barakowozy, obiekty kontenerowe.

Mając na uwadze powyższe, można dojść do wniosku, że hala namiotowa jest bez wątpienia tymczasowym obiektem budowlanym, który nie jest trwale połączony z gruntem. Pojęcie „niepołączenia (niezwiązania) trwałego z gruntem” oznacza, m.in. nieposiadanie przez ten obiekt budowlany fundamentów, które są usytuowane poniżej poziomu terenu (wkopane w grunt). Ponadto każdego obiektu budowlanego, w którym

6 Orędownikiem takiego pomysłu jest m.in. prof. dr hab. L. Etel. Zob. wywiad udzielony „Rzeczpospolitej” z dnia 4.06.2012 r.; http://www.rp.pl/artykul/886508-LeonardEtel--podatek-od-nieruchomosci-do-zmiany.html\#ap-1. 
dolna płaszczyzna fundamentu znajduje się na poziomie terenu, a jego przeniesienie lub rozebranie nie wiąże się z wykonywaniem robót ziemnych, nie można uznać za trwale połączony (związany) z gruntem. Hala namiotowa spełnia tym samym wyżej wymienione kryteria. Nie jest przy tym z całą pewnością ani nieruchomością, ani budynkiem małej architektury.

Stąd też, jeżeli hala namiotowa jest obiektem budowlanym innym niż wyżej wymienione, to czy przez to można zakwalifikować ją do zakresu pojęcia „budowla” w rozumieniu u.p.b., a przez to uznać, iż kwalifikuje się ona do zakresu opodatkowania podatkiem od nieruchomości zgodnie $\mathrm{z}$ treścią u.p.o.l?

Wskazać jednak należy, że temat opodatkowania hal namiotowych jest $\mathrm{w}$ istocie dyskusyjny i wywołujący szereg wątpliwości, a przez to niepozwalający na zajęcie jednoznacznego stanowiska w zakresie podlegania lub nie tych obiektów podatkowi od nieruchomości. W ocenie autora istnieją jednakże argumenty, tj. wnioski z analizy treści powołanych wyżej przepisów prawa, zarówno podatkowego, jak i administracyjnego, dokonane w zgodzie z właściwą ich wykładnią oraz przy uwzględnieniu orzecznictwa sądowego ${ }^{7}$, które skłaniają do zajęcia stanowiska, iż obiekt budowlany taki jak hala namiotowa, nie powinien podlegać opodatkowaniu podatkiem od nieruchomości, bowiem nie kwalifikuje się do zaliczenia jej jako budowla.

Przypomnieć należy, że przepisy ustaw podatkowych w sprawach sobie właściwych cechuje pewna autonomia i zakłada się przy tym, iż winny one charakteryzować się tzw. podwyższonym standardem legislacji. Czytelność przekazu zawartego w ustawie podatkowej, który zawarł ustawodawca, musi być realna, a nie pozorna, bowiem na tym, m.in. założeniu opiera się realizowanie powszechnego obowiązku podatkowego (opodatkowania).

Analizując treść u.p.o.l. w części dotyczącej przedmiotu opodatkowania, stwierdzić należy, że kryteria te w pewnym sensie zostały spełnione.

7 Np. uchwała siedmiu sędziów NSA z dnia 3 lutego 2014 r., sygn. akt II FPS 11/13 (ONSAiWSA 2014/4/58); wyrok WSA w Olsztynie z dnia 14 stycznia 2015 r., I SA/OI 911/14, LEX nr 1622285; wyrok WSA w Poznaniu z dnia 6 marca 2014 r., III SA/Po 1274/13, Centralna Baza Orzeczeń Sądów Administracyjnych (CBOSA). 
Zgodnie $\mathrm{z}$ art. 1a ust. 1 pkt 1 u.p.o.l. budowla to obiekt budowlany w rozumieniu przepisów prawa budowlanego niebędący budynkiem lub obiektem małej architektury, a także urządzenie budowlane w rozumieniu przepisów prawa budowlanego związane z obiektem budowlanym, które zapewnia możliwość użytkowania obiektu zgodnie z jego przeznaczeniem. Dla potrzeb odczytania właściwego zakresu definicji budowli ustawodawca nie tworzy już nowej definicji w treści i dla potrzeb u.p.o.l. uznając, iż definicja budowli zawarta w u.p.b. jest wystarczająca dla stosowania jej w tej ustawie podatkowej. Jest to odesłanie często stosowane przy odkodowywaniu i stosowaniu norm prawa podatkowego, bowiem nie ma potrzeby mnożenia definicji, których znaczenie dla potrzeb kilku aktów normatywnych byłoby identyczne.

Stąd też, przenosząc powyższe na grunt u.p.o.l. zgodnie $\mathrm{z}$ intencją ustawodawcy, budowla jest obiektem budowlanym zgodnie z brzmieniem art. 3 pkt 1 u.p.b. Budowlą natomiast jest każdy obiekt budowlany niebędący budynkiem lub obiektem małej architektury, jak: obiekty liniowe, lotniska, mosty, wiadukty, estakady, tunele, przepusty, sieci techniczne, wolno stojące maszty antenowe, wolno stojące trwale związane z gruntem urządzenia reklamowe, budowle ziemne, obronne (fortyfikacje), ochronne, hydrotechniczne, zbiorniki, wolno stojące instalacje przemysłowe lub urządzenia techniczne, oczyszczalnie ścieków, składowiska odpadów, stacje uzdatniania wody, konstrukcje oporowe, nadziemne i podziemne przejścia dla pieszych, sieci uzbrojenia terenu, budowle sportowe, cmentarze, pomniki, a także części budowlane urządzeń technicznych (kotłów, pieców przemysłowych, elektrowni wiatrowych, elektrowni jądrowych i innych urządzeń) oraz fundamenty pod maszyny i urządzenia, jako odrębne pod względem technicznym części przedmiotów składających się na całość użytkową. Tak stanowi przepis art. 3 pkt 3 u.p.b.

Treść powołanych przepisów jest na tyle czytelna, że aby uznać określony obiekt za budowlę na potrzeby u.p.o.l., wystarczające powinno być odnalezienie tego obiektu $\mathrm{w}$ treści art. 3 pkt 3 u.p.b. Przepis ten, w mojej ocenie, zawiera konkretny zwrot, a mianowicie: „przez budowlę [...], należy rozumieć każdy obiekt budowlany niebędący budynkiem lub obiektem małej architektury, jak:”, a po nim następuje enumeratywne, 
a nie przykładowe wyliczenie rzeczy (obiektów) zaliczanych do zakresu definicji „budowla”. Jest to normatyw bardziej przemawiający za tym, że ma on charakter zamknięty i jest wyliczeniem, które nie powinno pozwalać na uzupełnienie go czynnościami interpretacyjnymi w sposób rozszerzający o inne obiekty, których ustawodawca tam po prostu nie wymienił. Gdyby tego chciał ustawodawca, dając pewien luz interpretacyjny, wyraźnie zawarłby tam co najmniej taki zwrot „każdy obiekt budowlany, a w szczególności”, a nie zwrot „każdy obiekt budowlany, jak”.

Odmienny pogląd wyrażają niektórzy reprezentanci doktryny, którzy uznają, iż przetoczona definicja w art. 3 pkt 3 u.p.b. jest przykładowym jedynie wyliczeniem obiektów budowlanych, które należy uznać za budowlę, czyli nie jest to wyliczenie zamknięte ${ }^{8}$.

W ocenie autora stanowisko to stoi nieco w sprzeczności z zasadami legislacji, regulowanymi treścią Rozporządzenia Rady Ministrów z dnia 20 czerwca 2002 r. w sprawie „Zasad techniki prawodawczej”9 . Otóż, przyjmując za typowymi środkami techniki prawodawczej, zgodnie z § 153 ust. $3 \mathrm{w}$ zakresie konstruowania definicji w aktach normatywnych, w przypadku gdy nie jest możliwe sformułowanie definicji zakresowej, można objaśnić znaczenie danego określenia przez przykładowe wyliczenie jego zakresu, wyraźnie wskazując przykładowy charakter wyliczenia przez posłużenie się zwrotem: „w szczególności”.

Stąd też, gdyby uznać, że definiowane budowle w treści art. 3 pkt 3 u.p.b. miałyby być wyliczeniem jedynie przykładowym, to ten właśnie zwrot powinien stanowić element konstrukcyjny tego przepisu. Użycie natomiast zwrotu ,jak” nie powinno być utożsamiane ze zwrotem „w szczególności”.

Skłania mnie to również do przyjęcia wniosku, że w tak szczególnej materii, jaką jest prawo podatkowe, nawet przy zapożyczeniu dla jego stosowania definicji pochodzących z innych aktów normatywnych, nie powinno być ono interpretowane rozszerzająco. Dyskusyjna problematyka opodatkowania budowli wydaje się w niektórych sprawach podatkowych

8 L. Etel (red.), Europejskie systemy opodatkowania nieruchomości, Warszawa 2003, s. 190 i n.

$9 \quad$ Tekst jedn. Dz.U z 2016 r., poz. 283. 
potwierdzać tę niekorzystną tendencję, a więc i próbę zaliczania do budowli hal namiotowych, których to nie wymienił przecież ustawodawca w treści art. 3 pkt 3 u.p.b. Pojęcie „hala namiotowa” nie mieści się w ogóle w zakresie pojęciowym wymienionych tam obiektów (rzeczy). Czyż nie jest to jeden z głównych argumentów logicznie pozwalający na wyłączenie hal namiotowych z zakresu pojęciowego budowli, objętych zakresem przepisu art. 3 pkt 3 u.p.b?

Dokonując wykładni przytoczonych wyżej przepisów, trzeba pamiętać, że w sprawie dotyczącej określenia zobowiązania podatkowego należy kierować się zasadą szczególnej określoności regulacji daninowych, która sprowadza się do wymogu, aby wszystkie elementy stosunku podatkowego, w tym dotyczące przedmiotu opodatkowania, zostały określone w akcie rangi ustawowej w sposób dostatecznie precyzyjny i jasny ${ }^{10}$.

Powyższe stanowisko wzmacniać powinien kolejny wniosek, który był przytaczany już wcześniej, wskazujący na wyłączenie hal namiotowych z zakresu definicji „,budowli”, bowiem kwalifikowane są one do tymczasowych obiektów budowlanych, które nie są trwale połączone z gruntem. Obiekty te są zdefiniowane treścią przepisu art. 3 pkt 5 u.p.b., a nie przepisu art. 3 pkt 3 u.p.b. Zastrzec również należy, iż skoro konkretny obiekt budowlany jest definiowany w konkretnym przepisie ustawy, to nie może być taki sam obiekt odmiennie definiowany w innym przepisie takiego samego aktu normatywnego. Taki stan uznać należałoby za nielogiczny i sprzeczny z intencją ustawodawcy oraz z zasadami prawidłowej legislacji.

\section{Podsumowanie}

Podstawą podjęcia się analizy wycinka rzeczywistości podatkowej, a dotyczącej zakresu opodatkowania podatkiem od nieruchomości, takich obiektów jak hale namiotowe, był bez wątpienia zarysowujący się od pewnego czasu problem interpretacyjny $\mathrm{w}$ tym obszarze. Problem ten

10 Wyrok Trybunału Konstytucyjnego z dnia 18 lipca 2013 r., sygn. akt SK 18/09, Dz.U. poz. 985, OTK ZU nr 6/A/2013, poz. 80. 
pojawił się w przedmiocie stosowaniu prawa podatkowego przez organy podatkowe samorządu terytorialnego, które z pewnością nie do końca właściwie odczytują treść postanowień u.p.o.l. W dalszej konsekwencji prowadziło i prowadzi to do rozstrzygania spraw podatkowych na niekorzyść podatników, którzy będąc właścicielami hal namiotowych, w ocenie organów podatkowych winni je zgłaszać do opodatkowania. Zdaniem autora takie stanowisko organów podatkowych jest pozbawione podstaw prawnych.

Wypada pokusić się o twierdzenie - a czynię to z pewnym zasmuceniem - iż komunikowane podatnikom w aktach administracyjnych (interpretacjach podatkowych, decyzjach wydanych zarówno w I, jak i w II instancji) stanowiska samorządowych organów podatkowych, wynikają z pewnością z niezrozumienia zasad legislacji podatkowej albo zasad legislacji w ogóle.

Przyjąć przy tym należy fakt aktualnie występujących wątpliwości w obszarze klasyfikowania dla potrzeb podatku od nieruchomości hal namiotowych, tym niemniej przytoczony powyżej obowiązujący stan prawny odczytany w zgodzie z zasadami legislacji skłania do opowiedzenia się za stanowiskiem, że te obiekty nie podlegają opodatkowaniu podatkiem od nieruchomości.

Co prawda, ustawodawca nieco uprościł sobie sytuację, nie definiując budowli i budynku wprost w u.p.o.l., lecz posłużył się definicjami $\mathrm{z}$ innego aktu normatywnego, to z całą pewnością taki zabieg nie godzi w standardy legislacyjne przewidziane dla prawa podatkowego, a w szczególności zasadę ustawowej określoności regulacji podatkowych i zasadę poprawnej legislacji, wywodzonych z art. 217 w związku z art. 84 i art. 2 Konstytucji RP. Skoro poprzez owo odesłanie określił, co należy rozumieć pod pojęciem budowli, to organom podatkowym nie przynależy kompetencja rozszerzającego interpretowania prawa podatkowego, a przez to zaliczania do zakresu opodatkowania więcej przedmiotów (tu: obiektów), niż miałoby to wynikać z prawidłowej wykładni przepisów u.p.o.l. w związku z u.p.b. W badanym stanie prawnym oznaczałoby to niejako dokonywanie subsumpcji, a tego organom podatkowym czynić nie wolno. Winny one wyłącznie wykonywać prawo, a nie podciągać treść 
przepisów prawa pod określony stan faktyczny, którego celem jest wyłącznie cel fiskalny.

Przytoczyć w tym miejscu należy z całą pewnością ważne w obszarze badanego zagadnienia kolejne orzeczenie Trybunału Konstytucyjnego z dnia 13 września 2011 r., a dotyczące opodatkowania wyrobisk górniczych (konstytucyjności przepisów art. 2 ust. 1 pkt 3 w związku z art. 1a ust. 1 pkt 2 u.p.o.l. $)^{11}$, w którym to Trybunał wyraźnie wskazał kierunek interpretacji i stosowania przepisów prawa podatkowego. Przypomniał przy tym, iż w przypadku pojawienia się (czy też uznania przez interpretatorów prawa), że istnieją niejasne regulacje podatkowe, nie wolno ich interpretować na niekorzyść podatników, a ich analogiczne czy rozszerzające stosowanie jest niedopuszczalne w każdym przypadku, gdy ma na celu zwiększenie obowiązków podatkowych. Co więcej, TK wskazał również, iż nie ma przeszkód w opodatkowaniu konkretnych obiektów i urządzeń podatkiem od nieruchomości jeżeli, m.in. dają się one zakwalifikować jako budowle wymienione expressis verbis w art. 3 pkt 3 u.p.b.

Stąd też, należałoby przypomnieć niektórym interpretatorom prawa, którzy mają wątpliwości co do zakresu normowania poszczególnych przepisów prawa podatkowego, a w szczególności u.p.o.l., iż zgodnie z podstawowymi zasadami konstytucyjnymi, to zasada in dubio pro tributario ma pierwszeństwo przed zasadą in dubio pro fisco.

\section{Bibliografia:}

Etel L. (red)., Europejskie systemy opodatkowania nieruchomości, Kancelaria Sejmu, Warszawa 2003.

Wronkowska S., Zieliński M., Komentarz do zasad techniki prawodawczej, Wydawnictwo Sejmowe, Warszawa 2004.

11 Sygn. akt P 33/09, Dz.U. Nr 206, poz. 1228. 